\title{
Genome analysis of Spiroplasma citri strains from different host plants and its leafhopper vectors
}

Rachel Rattner ${ }^{1 \dagger}$, Shree Prasad Thapa ${ }^{2 \dagger}$, Tyler Dang ${ }^{3}$, Fatima Osman², Vijayanandraj Selvaraj ${ }^{1}$, Yogita Maheshwari ${ }^{1}$, Deborah Pagliaccia ${ }^{3}$, Andres S. Espindola ${ }^{4}$, Subhas Hajeri', Jianchi Chen ${ }^{1}$, Gitta Coaker², Georgios Vidalakis ${ }^{3}$ and Raymond Yokomi ${ }^{1 *}$ (D)

\begin{abstract}
Background: Spiroplasma citri comprises a bacterial complex that cause diseases in citrus, horseradish, carrot, sesame, and also infects a wide array of ornamental and weed species. S. citri is transmitted in a persistent propagative manner by the beet leafhopper, Neoaliturus tenellus in North America and Circulifer haematoceps in the Mediterranean region. Leafhopper transmission and the pathogen's wide host range serve as drivers of genetic diversity. This diversity was examined in silico by comparing the genome sequences of seven $\mathrm{S}$. citri strains from the United States (BR12, CC-2, C5, C189, LB 319, BLH-13, and BLH-MB) collected from different hosts and times with other publicly available spiroplasmas.

Results: Phylogenetic analysis using 165 rRNA sequences from 39 spiroplasmas obtained from NCBI database showed that S. citri strains, along with S. kunkelii and S. phoeniceum, two other plant pathogenic spiroplasmas, formed a monophyletic group. To refine genetic relationships among S. citri strains, phylogenetic analyses with 863 core orthologous sequences were performed. Strains that clustered together were: CC-2 and C5; C189 and R8-A2; BR12, BLH-MB, BLH-13 and LB 319. Strain GII3-3X remained in a separate branch. Sequence rearrangements were observed among S. citri strains, predominantly in the center of the chromosome. One to nine plasmids were identified in the seven S. citri strains analyzed in this study. Plasmids were most abundant in strains isolated from the beet leafhopper, followed by strains from carrot, Chinese cabbage, horseradish, and citrus, respectively. All these S. citri strains contained one plasmid with high similarity to plasmid pSci6 from S. citri strain Gll3-3X which is known to confer insect transmissibility. Additionally, 17 to 25 prophage-like elements were identified in these genomes, which may promote rearrangements and contribute to repetitive regions.

(Continued on next page)
\end{abstract}

\footnotetext{
* Correspondence: ray.yokomi@usda.gov

${ }^{\dagger}$ Rachel Rattner and Shree Prasad Thapa contributed equally to this work.

${ }^{1}$ Crop Diseases, Pests, and Genetics Research Unit, San Joaquin Valley

Agricultural Sciences Center, USDA Agricultural Research Service, Parlier, CA 93648, USA

Full list of author information is available at the end of the article
}

(c) The Author(s). 2021 Open Access This article is licensed under a Creative Commons Attribution 4.0 International License, which permits use, sharing, adaptation, distribution and reproduction in any medium or format, as long as you give appropriate credit to the original author(s) and the source, provide a link to the Creative Commons licence, and indicate if changes were made. The images or other third party material in this article are included in the article's Creative Commons licence, unless indicated otherwise in a credit line to the material. If material is not included in the article's Creative Commons licence and your intended use is not permitted by statutory regulation or exceeds the permitted use, you will need to obtain permission directly from the copyright holder. To view a copy of this licence, visit http://creativecommons.org/licenses/by/4.0/. The Creative Commons Public Domain Dedication waiver (http://creativecommons.org/publicdomain/zero/1.0/) applies to the data made available in this article, unless otherwise stated in a credit line to the data. 


\begin{abstract}
(Continued from previous page)
Conclusions: The genome of seven S. citri strains were found to contain a single circularized chromosome, ranging from $1.58 \mathrm{Mbp}$ to $1.74 \mathrm{Mbp}$ and 1597-2232 protein-coding genes. These strains possessed a plasmid similar to pSci6 from the GII3-3X strain associated with leafhopper transmission. Prophage sequences found in the S. citri genomes may contribute to the extension of its host range. These findings increase our understanding of $S$. citri genetic diversity.
\end{abstract}

Keywords: Citrus stubborn disease, Beet leafhopper, Spiroplasma, Sequencing, Genome assembly, Prophage

\section{Background}

Spiroplasmas (helical mollicutes: Firmicutes: Mollicutes: Entomoplasmatales: Spiroplasmataceae) are wall-less, gram-positive bacteria with mobile helical cells. The bacteria are fastidious, culturable in cell-free media [1], and have a diverse host range [2]. Spiroplasmas are found in many arthropods including bees, flies, mosquitos, scorpion flies, beetles, and ticks [2] and have host relationships that range from commensal, mutualistic, and pathogenic [3]. Plant pathogenic spiroplasmas cause economic damage to crops and ornamentals. These pathogens include: Spiroplasma citri, causal agent of citrus stubborn disease (CSD) [4], brittle root of horseradish [5], and carrot purple leaf [6]; S. kunkelli, the causal agent of corn stunt [7]; and S. phoeniceum, isolated from periwinkle showing symptoms typical of mycoplasma-like organisms [8]. Plant pathogenic spiroplasmas are transmitted in a persistent propagative manner by leafhoppers. Vectors of S. citri are the beet leafhopper (BLH), Neoaliturus (syn. Circulifer) tenellus (Baker) [9] in North America and Circulifer haematoceps (Mulsant et Rey) in the Mediterranean region [10]. S. kunkelli is transmitted by Dalbulus maidis (DeLong) [7] and S. phoeniceum was experimentally transmitted by Macrosteles fascifrons (Stål) [8].

Characterization of spiroplasmas have been based on morphological and biological properties. However, because growth, metabolism, and DNA-DNA relatedness studies are time consuming, serological deformation tests and enzyme-linked immunosorbent assays have been used for identification of new spiroplasma groups in accordance to the International Subcommittee on the Taxonomy of Mycoplasmatales [2, 11]. Recently, longread high-throughput sequencing technology and whole genome sequencing of bacteria have become costeffective and offers a precise method to differentiate bacterial species and strains that have highly repetitive regions in its genome [12, 13].

The pathogen's wide host range and vector transmission serve as bottlenecks and drivers of genetic diversity of $S$. citri populations. Although S. citri exist in free living form in insect hemolymph and appropriate culture media, the pathogen in the vector must enter and move through the salivary gland and exit into the salivary duct and be expelled by the vector during probing and/or feeding in plants where $S$. citri infects host phloem tissue and exists intracellularly and is phloem-limited. Therefore, the objective of this study is to examine the genomes of S. citri collected from diverse hosts from different locations and times; and analyze the relationship between the genotype and phenotype of $S$. citri from citrus and horseradish (perennial crops); carrot and Chinese cabbage (annual crops); and from the BLH vector. The analysis was performed on whole-genome sequences of seven newly sequenced strains of $S$. citri and compared amongst each other, other S. citri strains, and spiroplasmas from other hosts. New insights in the evolution and diversity of $S$. citri is presented herein.

\section{Results}

\section{Genome assembly and annotation}

Cultures of six strains of Spiroplasma citri were established and sequences reported previously (Table 1) [14, 15] and a new strain, C5, is reported here. Briefly, S. citri strains C189 and LB 319 were isolated from the woody crop, citrus. BR12, CC-2, and C5 strains were isolated from the seasonal crops such as horseradish, Chinese cabbage, and carrot, respectively. BLH-13 and BLH-MB strains were isolated from the BLH. The complete genomes of the six strains were acquired using the longread technology, PacBio [14, 15] and C5 was obtained using Nanopore sequencing technology. Sequences from each strain were assembled into single chromosomal contigs. Contigs that did not associate with the chromosome were designated as putative plasmids (Table 2). The chromosome and plasmid status of each contig were further confirmed by BLASTn analyses against the GenBank database Release 236 (Supplementary Table S1). The circular chromosome for all seven strains ranged from $1,576,550$ to $1,742,208 \mathrm{bp}$, with an average $\mathrm{G}+\mathrm{C}$ content of $25.4 \%$. Total genome size ranged from $1,611,714$ to $1,832,173 \mathrm{bp}$ in strains isolated from plants and $1,968,976$ to $2,155,613 \mathrm{bp}$ in strains isolated from the BLH. Annotation of each contig was performed by the NCBI Prokaryotic Genome Annotation Pipeline (PGAP), which predicted 32 tRNA genes, three rRNA genes and protein-coding genes which ranged between 1597 and 2232. Extrachromosomal DNAs, characterized as putative plasmids varied in all the strains viz., one or 
Table 1 Spiroplasma citri strains analyzed in this study

\begin{tabular}{lllll}
\hline Strain & Host & Location & Year of collection & Reference \\
\hline C189 & Citrus & Riverside, California & 1960 & {$[14]$} \\
LB 319 & Citrus & Ducor, California & 2007 & {$[14]$} \\
BR12 & Horseradish & Collinsville, Illinois & 1984 & {$[14]$} \\
CC-2 & Chinese cabbage & Fresno, California & 2016 & {$[15]$} \\
C5 & Carrot & Bakersfield, California & 2005 & This study \\
BLH-13 & Beet leafhopper & Mettler, California & 2010 & {$[14]$} \\
BLH-MB & Beet leafhopper & Parlier, California & 2011 & {$[14]$} \\
\hline
\end{tabular}

two plasmids from citrus, two plasmids from horseradish, three plasmids from Chinese cabbage, seven plasmids from carrot, and eight or nine plasmids from the BLH. Putative plasmid sizes ranged from $2047 \mathrm{bp}$ to 135, 023 bp (Supplementary Table S1). Seven of the 32 plasmids identified in these seven strains could not be circularized and further research is needed to determine if they are linear or products of sequencing error or culturing conditions.

\section{Phylogenomics}

Molecular phylogenetic inference of 39 spiroplasmas was performed using $16 \mathrm{~S}$ rRNA genes in the NCBI database. Analysis of this gene sequence indicated that $S$. citri strains are closely related, but not identical. The phylogeny inferred from the 16S rRNA gene shows that $S$. citri strains formed a monophyletic group with plant pathogenic S. kunkelii, S. phoeniceum, and a honeybee pathogen, S. melliferum (Fig. 1, Supplementary Table S2). To facilitate a high-resolution comparison of $S$. citri strains, core genomes were analyzed for nine $S$. citri genomes available in NCBI. Using the orthoMCL pipeline, a total of 863 orthologous genes were identified as conserved among the $S$. citri strains. The 863 orthologous genes were concatenated, and a maximum-likelihood approach was employed to generate a $S$. citri phylogeny (Fig. 2). Phylogenetic analyses with the core orthologous sequences among the $S$. citri strains showed citrus strains C189 from southern California and R8-A2 from Morocco clustered together. CC-2, isolated from Chinese cabbage, and $\mathrm{C} 5$, isolated from carrot, clustered together. Strains LB 319, BLH-13, BLH-MB, and BR12 clustered together in a separate clade. There was clear separation of S. citri from S. kunkelii (Supplementary Fig. S1).

\section{Comparative genomics}

The circular chromosome of the seven S. citri strains from the U.S. was compared via BLASTn to the R8A2 strain from citrus in Morocco as the reference

Table 2 Genome assembly statistics for Spiroplasma citri strains analyzed in this study

\begin{tabular}{|c|c|c|c|c|c|c|c|}
\hline Spiroplasma citri strain & $\begin{array}{l}\text { S. citri } \\
\text { C189 }\end{array}$ & $\begin{array}{l}\text { S. citri } \\
\text { LB } 319\end{array}$ & $\begin{array}{l}\text { S. citri } \\
\text { BR12 }\end{array}$ & $\begin{array}{l}\text { S. citri } \\
\text { CC-2 }\end{array}$ & $\begin{array}{l}\text { S. citri } \\
\text { C5 }\end{array}$ & $\begin{array}{l}\text { S. citri } \\
\text { BLH-13 }\end{array}$ & $\begin{array}{l}\text { S. citri } \\
\text { BLH-MB }\end{array}$ \\
\hline Chromosome size (bp) & $1,577,041$ & $1,734,522$ & $1,731,112$ & $1,709,192$ & $1,618,536$ & $1,576,550$ & $1,742,208$ \\
\hline $\begin{array}{l}\text { Combined size of } \\
\text { plasmids (bp) }\end{array}$ & 34,663 & 95,488 & 101,061 & 82,444 & 126,436 & 392,426 & 413,405 \\
\hline $\begin{array}{l}\text { Chromosome }+ \\
\text { plasmid size (bp) }\end{array}$ & $1,611,704$ & $1,830,010$ & $1,832,173$ & $1,791,636$ & $1,795,359$ & $1,968,976$ & $2,155,613$ \\
\hline No. of plasmids & 1 & 2 & 2 & 3 & 7 & 8 & 9 \\
\hline $\begin{array}{l}\text { Chromosome GC } \\
\text { content (\%) }\end{array}$ & 25.6 & 25.4 & 25.4 & 25.6 & 25.6 & 25.4 & 25.4 \\
\hline Total no. genes & 1946 & 2207 & 2200 & 2068 & 2064 & 2594 & 2411 \\
\hline $\begin{array}{l}\text { Total protein-coding } \\
\text { genes }\end{array}$ & 1597 & 1853 & 1876 & 1716 & 1701 & 2232 & 2082 \\
\hline Total rRNA genes & 3 & 3 & 3 & 3 & 3 & 3 & 3 \\
\hline Total tRNA genes & 32 & 32 & 32 & 32 & 32 & 32 & 32 \\
\hline GenBank Accessions & $\begin{array}{l}\text { CP047426.1, } \\
\text { CP047427.1 [15] }\end{array}$ & $\begin{array}{l}\text { CP046371.1 - } \\
\text { CP046373.1 [15] }\end{array}$ & $\begin{array}{l}\text { CP046368.1 - } \\
\text { CP046370.1 [15] }\end{array}$ & $\begin{array}{l}\text { CP042472.1 - } \\
\text { CP042475.1 [14] }\end{array}$ & $\begin{array}{l}\text { CP053304.1 - } \\
\text { CP053311.1 } \\
\text { (this study) }\end{array}$ & $\begin{array}{l}\text { CP047428.1 - } \\
\text { CP047436.1 [15] }\end{array}$ & $\begin{array}{l}\text { CP047437.1 - } \\
\text { CP047446.1 [15] }\end{array}$ \\
\hline
\end{tabular}




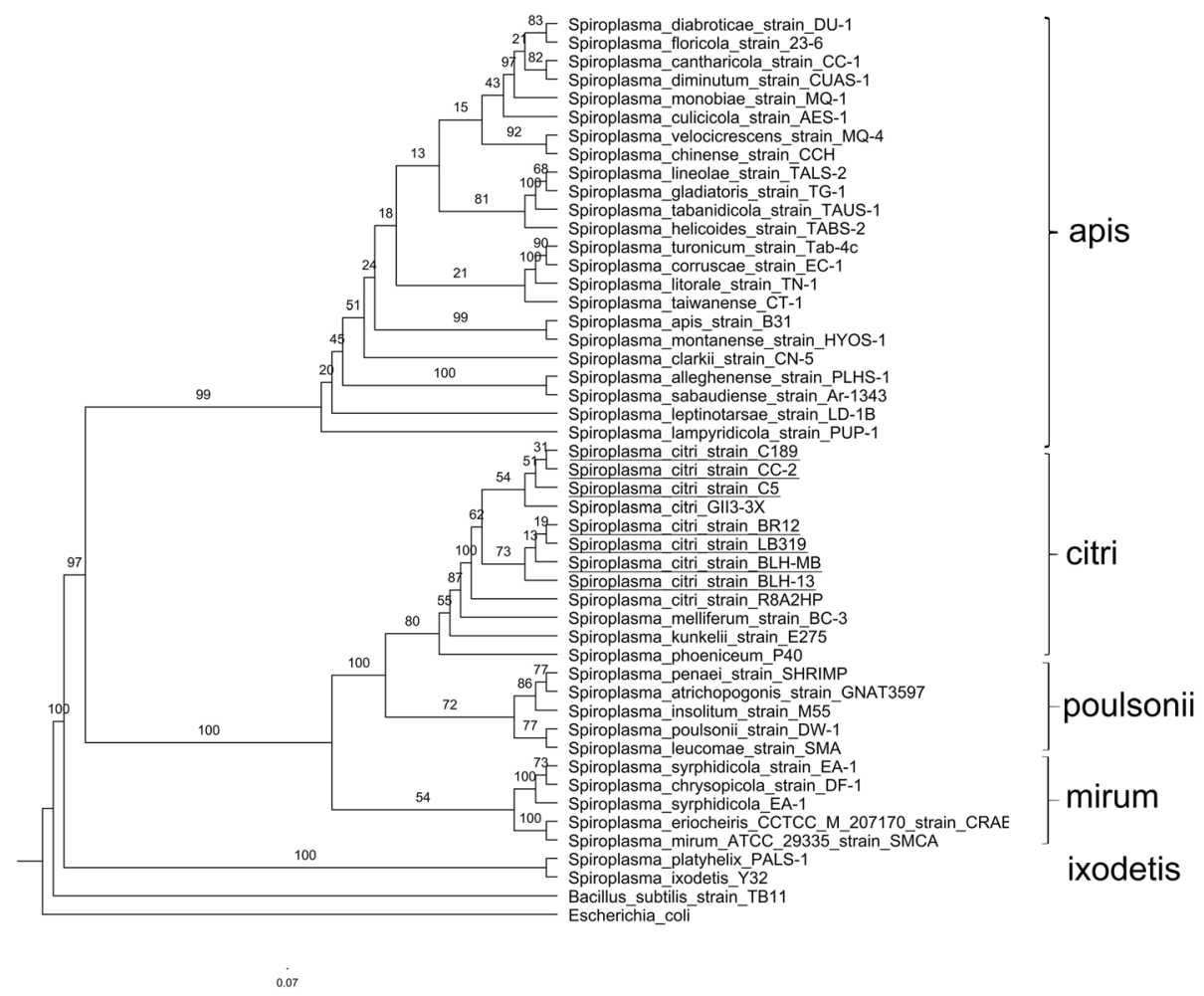

Fig. 1 Maximum-likelihood 16S rRNA phylogenetic analysis of Spiroplasma species. A maximum-likelihood approach was used to generate the phylogeny with 1000 bootstrap replicates. Bootstrap values are indicated at each node. The resulting phylogeny was visualized using FigTree $\mathbf{v}$. 1.4.3 [16]. S. citri strains analyzed in this report are underlined

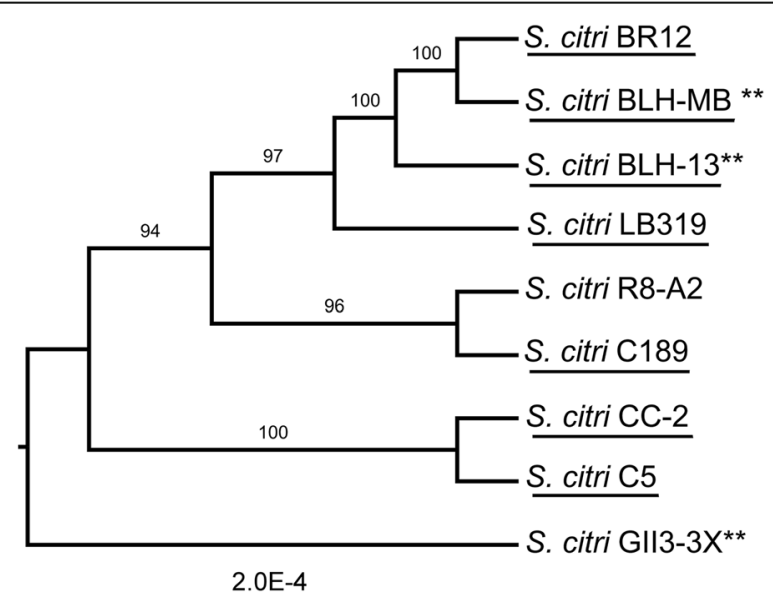

Fig. 2 Phylogenetic analysis of Spiroplasma citri strains. Maximumlikelihood phylogeny of Spiroplasma based on core orthologous genes. In total, 863 orthologous genes were concatenated, and a maximum-likelihood approach was used to generate the phylogeny with 1000 bootstrap replicates. Bootstrap values are indicated at each node. The resulting phylogeny was visualized using FigTree $v$. 1.4.3 [16]. S. citri strains analyzed in this report are underlined. Strains isolated from beet leafhopper have been marked with asterisks (**) sequence. Visualization of these results was performed using the BLAST Ring Image Generator (BRIG). This genome level comparison among $S$. citri strains isolated from different sources showed a high level of homogeneity among each other and the reference genome, R8-A2 (Fig. 3). S. citri strains C189, LB 319, and BR-12, which were isolated from citrus and horseradish, appear most similar to R8-A2. A large region of dissimilarity near the middle of the chromosome is notable in the BLH-13 strain, ranging from $\sim 600 \mathrm{kbp}$ to $\sim 800 \mathrm{kbp}$. These differences were not found in the BLH-MB strain, but some variability in this region can be seen in CC-2 and C5.

Dot-matrix pairwise sequence comparisons revealed a highly repetitive region at $\sim 1200 \mathrm{kbp}$ (Supplementary Fig. S2). The repetitive region, marked in Fig. 3, is an area of higher dissimilarity in the chromosome among the $S$. citri strains analyzed in this study.

Pairwise whole genome comparisons were performed with S. citri strains BLH-13, LB 319, and CC-2 which were selected to represent the biological diversity in this study. This comparison revealed high genome similarity, higher numbers of shared genes, and limited genome re-arrangements as observed in the center region (Fig. 4a). In contrast, 


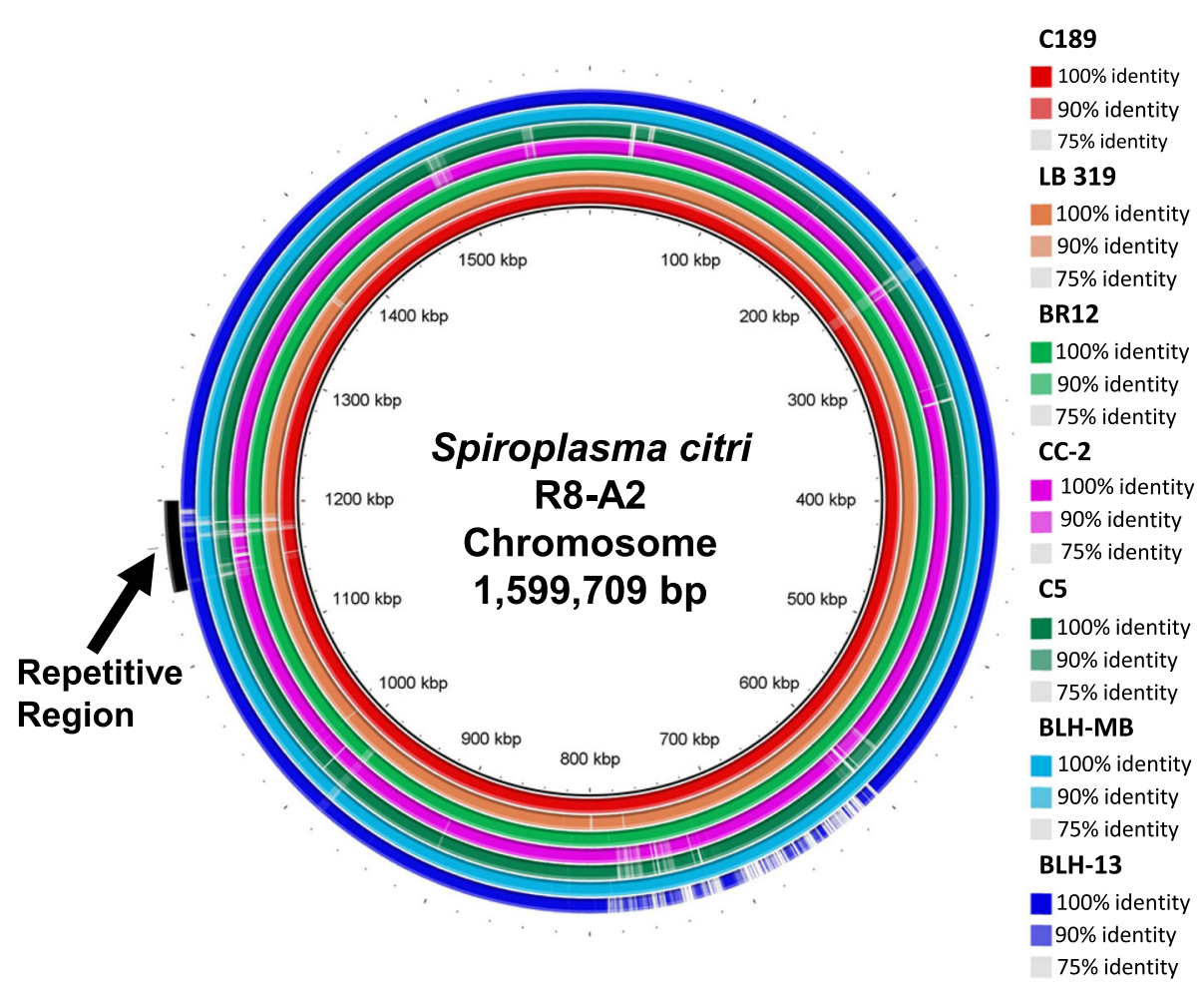

Fig. 3 BLASTn results of Spiroplasma citri chromosomes. Whole genome comparison of eight S. citri strains visualized by BLAST Ring Image Generator (BRIG) [17]. S. citri strain R8-A2 was used as a reference. Each of the illustrated rings refers to one S. citri strain's chromosome, according to the listed coloration. White regions represent dissimilarity from the reference genome. A highly repetitive region, marked in this image, was revealed during dot-matrix pairwise sequence comparisons (Supplementary Fig. S2). This area is marked based on the location of this region identified in the R8-A2 strain

genome comparison among different species of plant pathogenic spiroplasmas were examined using LB 319 from citrus, S. phoeniceum P40 from periwinkle, and S. kunkelii CR2-3X from corn. Here, S. citri, S. kunkelii, and S. phoeniceum showed significant differences in gene content, low level of genome similarity, and extensive genome rearrangements. S. kunkelii and $S$. phoeniceum also exhibited fewer regions of genome similarity and extensive genomic rearrangements (Fig. $4 b)$.

Homologous genes were also identified among LB 319, BLH-13, and CC-2 (Fig. 5a). These S. citri strains shared 990 core homologous gene clusters, with 42 and 43 homologous gene clusters specific to each of these strains. Among different plant pathogenic Spiroplasma spp., LB 319, S. phoeniceum P40, and S. kunkelii CR2-3X, shared 755 core homologous gene clusters (Fig. 5b). There were 201 to 424 homologous gene clusters specific to $S$. phoeniceum $\mathrm{P} 40$ and $S$. kunkelii CR2-3x, respectively. LB 319 shared 120 homologous gene clusters with $S$. phoeniceum, while sharing only 37 homologous isolated from S. kunkelii. Additionally, S. phoenicium and S. kunkelii shared 271 homologous gene clusters that were absent from LB 319 .

\section{Functional assignment of S. citri LB 319 protein-coding} sequences

Due to similarity of the chromosome of the seven S. citri strains studied, LB 319 was selected for further characterization. LB 319 had 1750 annotated protein coding sequences (CDS) and the functional classification of these protein coding sequences assigned only 553 CDS (32\%) in different clusters of orthologous groups (COGs). The most abundant functional category was DNA replication, recombination and repair, followed by translation. These categories mainly consist of gDNA polymerases (dnaE, dnaN, dnaX, holA, holB, polC), nucleotide excision repair ( $u v r A, u v r B, u v r C)$, DNA topoisomerases ( $\operatorname{gy} A$, gyrB, parC, parE), ribosomal proteins, and tRNA synthetases genes. Other important functional categories include translation (COG category $\mathrm{K}$ ), nucleotide metabolism and transport (COG category $\mathrm{F}$ ), and transcription (COG category O) (Fig. 6). Descriptive functional information of the genes is included in Supplemental Table S3. The low number of assigned COGs 
A)

S. citri BLH-13

$1,576,550 \mathrm{bp}$

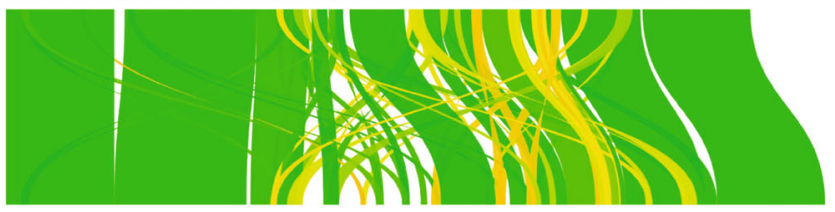

S. citri LB 319

$1,734,522$ bp

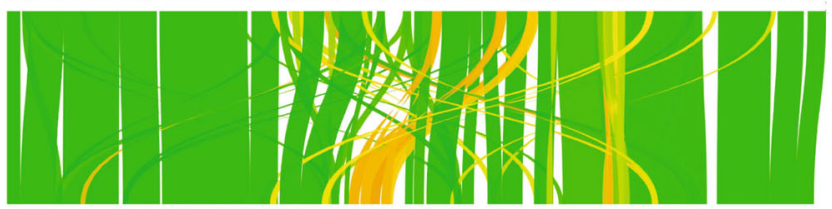

S. citri CC-2

$1,709,192 \mathrm{bp}$

B)

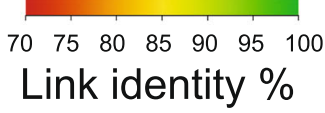

\section{S. kunkelii CR2-3x}

$1,463,926$ bp

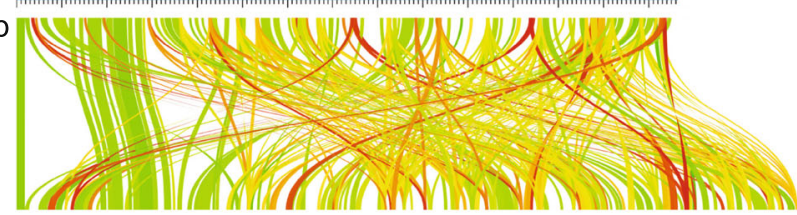

S. citri LB 319

$1,734,522$ bp

S. phoeniceum $\mathrm{P} 40$

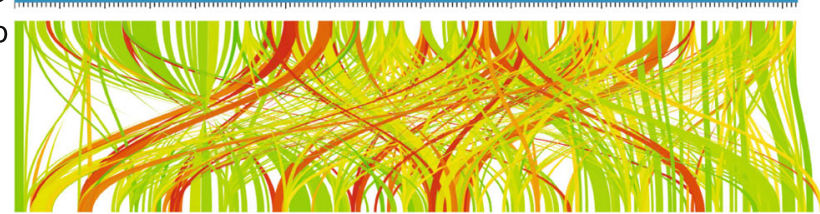

$1,791,576 \mathrm{bp}$

$$
\begin{array}{llllll}
70 & 75 \quad 80 & 85 & 90 & 95 & 100 \\
\text { Link identity \% }
\end{array}
$$

Fig. 4 Genome-wide comparison of pathogenic Spiroplasma species. Linear chromosomal maps were built using AliTV v. 1.0 visualization software [18], based on whole-genome alignments with Lastz v. 1.0.4 aligner [19]. Both panels depict pairwise comparisons, expressed as percentage of nucleotide similarity, that connect different homologous genomic regions. Chromosomes are completely finished and pictured in blue. a S. citri strains BLH-13 isolated from the beet leafhopper (BLH), LB 319 isolated from citrus and CC-2 isolated from Chinese cabbage. b S. citri LB 319, S. phoeniceum P40 and S. kunkelii CR2-3X

suggests that a large proportion of them may be fragments of unrecognized pseudogenes. Genes involved in mismatch repair like mutS, mutI, mutH, exoI, exoX, recI and genes involved in homologous recombination like $r e c A, r e c B$, $r e c C$ etc. are missing or truncated.

\section{Plasmid variability between S. citri strains}

Plasmids are genetic elements which may encode virulence factors and also play important roles in establishing host range [20-23]. Although a high level of similarity was found in the chromosome of $S$. citri strains, more diversity was found in the number of putative plasmids associated with these strains (Fig. 7a). For the sake of this study these putative plasmids are referred to as plasmids since the DNA in 25 of 32 plasmid-like contigs were circularized. Eight and nine plasmids were found in S. citri strains isolated from the BLH. Strains isolated from carrot and Chinese cabbage contained seven and three plasmids, respectively. S. citri strains isolated from citrus and horseradish possessed one to two plasmids. S. citri adhesionrelated proteins (ScARPs), which are expected to be involved in $S$. citri adhesion to insect cells $[25,26]$, were 

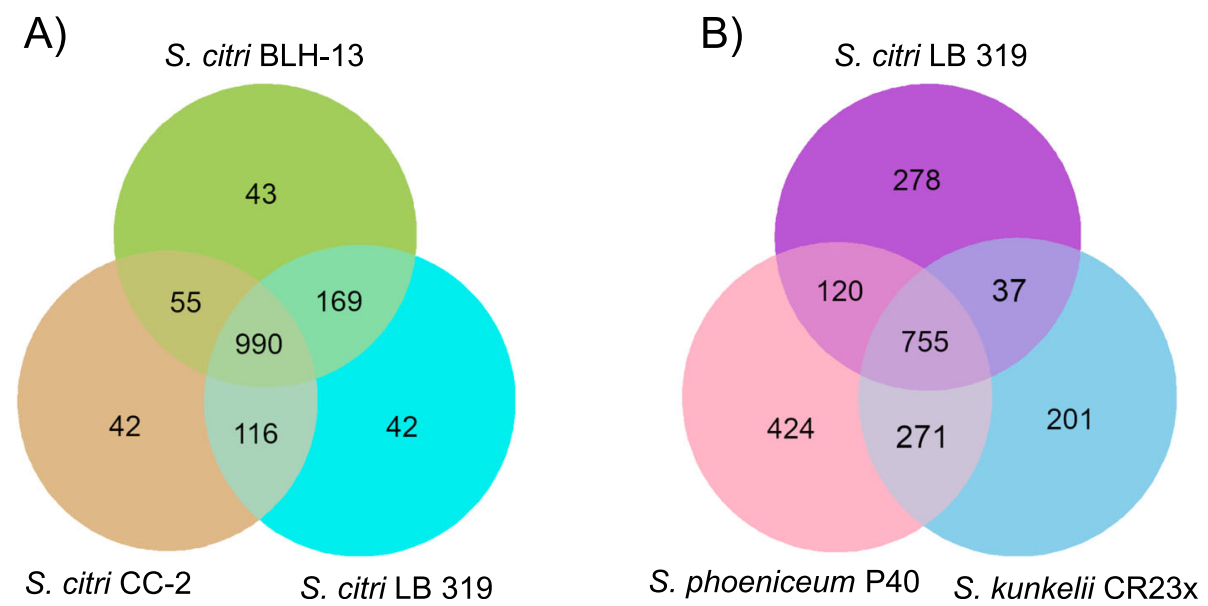

Fig. 5 Numbers of shared and genome-specific homologous gene clusters. The Venn diagrams show the number of shared and genome-specific homologous gene clusters among the genomes compared. a Comparison among Spiroplasma citri BLH-13, CC-2, and LB 319. b Comparison among S. citri LB 319, S. phoeniceum P40, and S. kunkelii CR2-3X

predicted in several plasmids by NCBI's Prokaryotic Genome Annotation Pipeline (PGAP). These ScARPs were present in one plasmid in BR12 and CC-2, two plasmids in $\mathrm{C} 5$ and BLH-MB, and three plasmids in BLH-13. No full-length ScARPs were predicted in C189 or LB 319 plasmids. S. citri strain C189, isolated from citrus in 1960, retained only one plasmid, pScp-C189-1. BLAST results revealed that this plasmid was highly similar to plasmid pSci6, identified in S. citri strain GII3-3X [24]. All strains analyzed in this study contained at least one plasmid with
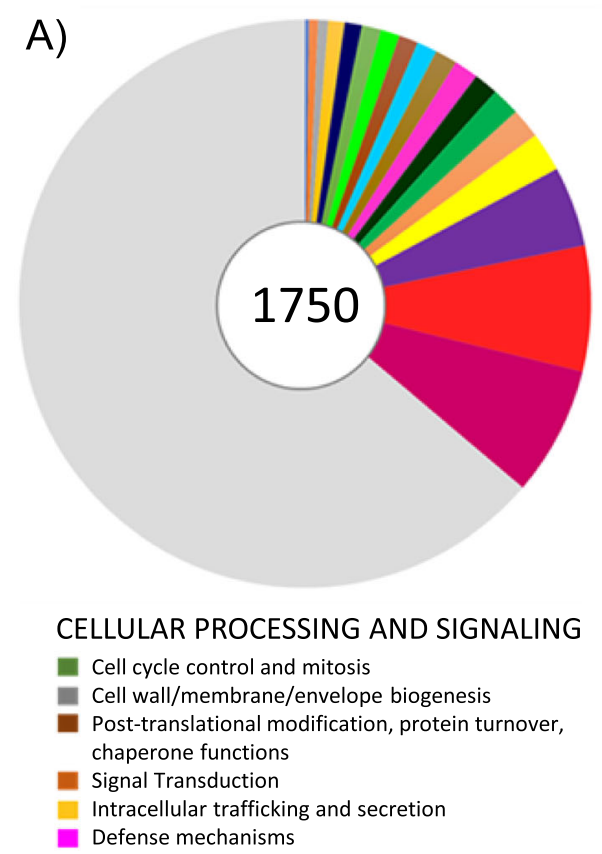

INFORMATION STORAGE AND PROCESSING

- Translation

Transcription

Replication and repair

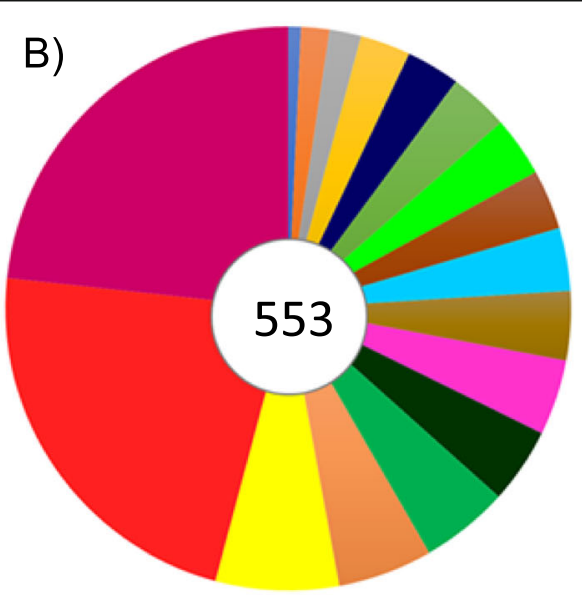

\section{METABOLISM}

Energy production and conversion Amino Acid metabolism and transport Nucleotide metabolism and transport

Carbohydrate metabolism and transport

Coenzyme metabolism

Lipid metabolism

Inorganic ion transport and metabolism

- Secondary Structure

\section{POORLY CHARACTERIZED}

- Function Unknown

No COG assignment

Fig. 6 Functional classification of protein-coding genes in S. citri LB 319. The functional categorization of each protein-coding gene was classified according to the COG assignments. The pie graph indicates the COG distribution statistics. Each color represents a COG functional description. a All annotated protein-coding genes in the S. citri LB 319 genome. b Protein-coding genes that could be assigned functional category 


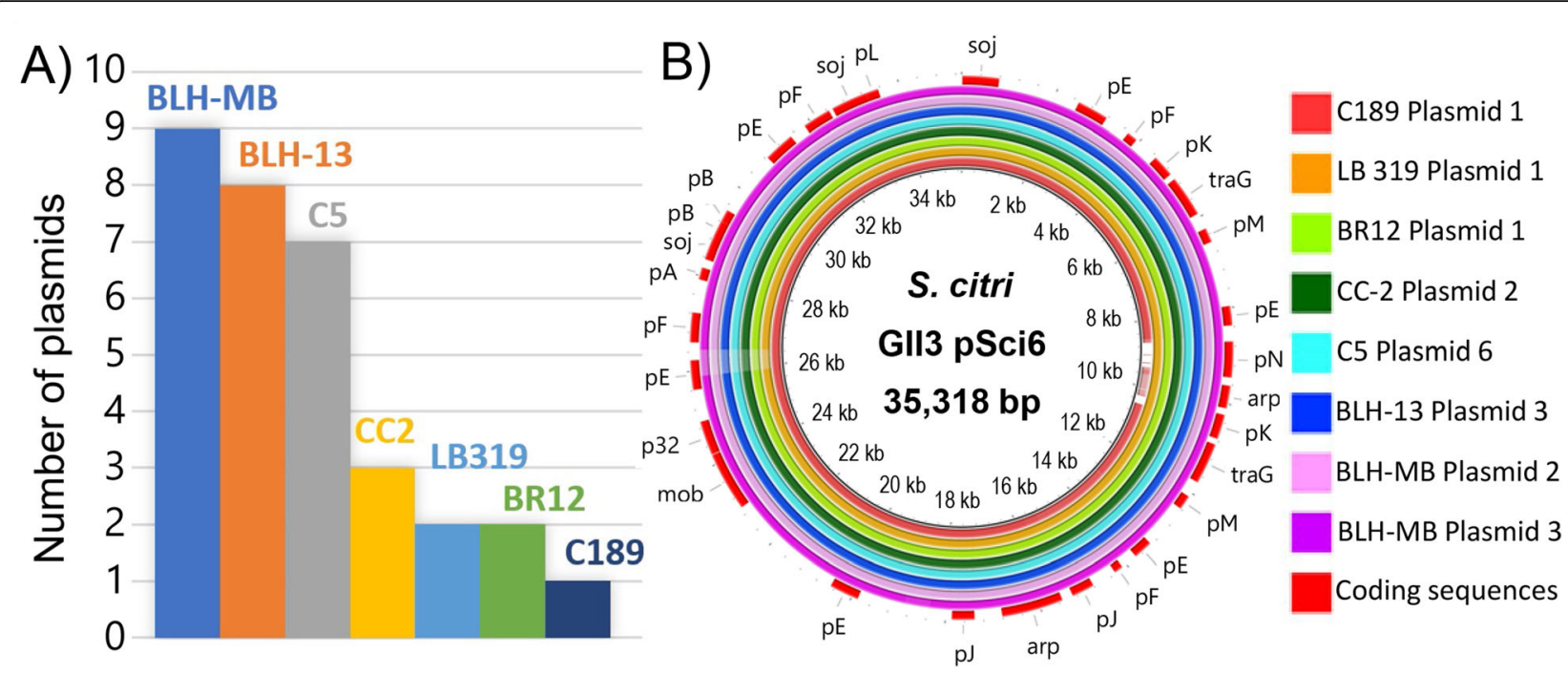

Fig. 7 Analysis of Spiroplasma citri plasmids. a Number of plasmids from each of the S. citri strains analyzed in this study. Each bar represents one strain and is labeled with the host that strain was collected from. $\mathbf{b}$ BLASTn results of conserved $S$. citri plasmid. Whole genome comparison of conserved S. citri plasmid visualized by BLAST Ring Image Generator (BRIG) [17]. Plasmid pSci6, identified in S. citri strain GII3-3X [24], was used as a reference. Each of the illustrated rings refers to $S$. citri plasmids identified in the seven other strains analyzed in this study that were closely related to pSci6. Lighter regions represent dissimilarity from the reference plasmid. Outermost ring denotes coding sequences and is labeled with gene names. pA-pN represent hypothetical proteins, as named in GenBank accession AJ969074 [24]

very high similarity to pSci6. (Fig. 7b). BLH-MB possessed two plasmids which resembled pSci6.

\section{Prophage prevalence in S. citri strains}

The PHASTER (PHAge Search Tool - Enhanced Release) web server was used to identify and annotate putative prophage regions within the $S$. citri genomes. Seventeen to 25 prophage-like elements were identified in the S. citri genomes (Supplementary Fig. S3). Plasmid pScpLB319-2 in LB 319 and pScpC5-3 in C5 contained prophage sequences (Supplementary Fig. S3 B,E). Two plasmids in BLH-13 (pSciBLH13-1 and pSciBLH13-6) and three plasmids in BLH-MB (pSciBLHMB-1, pSciBLHMB-7, and pSciBLHMB-8) possessed prophage sequences (Supplementary Fig. S3 F,G). No prophage sequences were predicted in plasmids from C189, BR12, or CC-2. A large proportion of these prophage sequences were homologous to plectrovirus SpV1 [27] and SVTS2 [28] (Supplementary Table S4). While multiple plectrovirus SpV1 sequences were found to be distributed throughout the chromosome, a concentrated area of SVTS2 sequences was found at approximately $1.2 \mathrm{Mbp}$. This region of the chromosome was found to have highly repetitive sequences in all $S$. citri genomes in this study as shown by dot-matrix pairwise sequence comparisons (Fig. 3, Supplementary Fig. S2). Further characterization of the prophage region in the chromosome and plasmids will be examined in the future.

\section{Putative virulence components in S. citri}

S. citri does not have specialized protein secretion apparatus, such as the type II and type III secretion systems. S. citri utilizes a sec-dependent protein export pathway. In S. citri LB 319, secY (GMI18_RS01645), secA (GMI18_RS01115), fts $Y$ (GMI18_RS00765), ffh (GMI18_ RS02240), secE (GMI18_RS01245), and yidC (GMI18_ RS10485) are the genes involved in the sec-dependent pathway and are conserved across $S$. citri strains. Several sequences in plasmid $\mathrm{pScp}-\mathrm{C} 189-1$ were homologous to genes associated with type IV secretion systems, including Mob-like transmembrane proteins, TraG proteins, and proteins containing TraM recognition domains and type IV secretion system DNA-binding domains. This plasmid is conserved across S. citri strains. Fructose operon genes are major pathogenicity determinants in $S$. citri [29, 30]. fruR (GMI18_RS08785), fruA (GMI18_ RS08780) and fruK (GMI18_RS08775) are genes present in the fructose operon and were present in all the $S$. citri strains analyzed in this study. fruR codes for bacterial transcriptional regulators of carbohydrate catabolic operons. fruA codes for the permease of the phosphoenolpyruvate:fructose phosphotransferase system. This fructose permease allows uptake and concomitant phosphorylation of fructose into fructose-1-phosphate. fruK codes for a 1- 
phosphofructokinase, which uses ATP to phosphorylate fructose-1-phosphate into fructose-1,6-bisphosphate [30].

\section{Discussion}

Prior to advances in long-read sequencing, the best assembly of $S$. citri was strain GII3-3X, which contained 39 chromosomal contigs [24]. The first sequence of $S$. citri containing a single chromosomal contig was reported in 2017 for Moroccan S. citri strain R8-A2 ${ }^{\mathrm{T}}$ [31]. Complete genomes, with single chromosomal contigs, of six more strains of $S$. citri isolated in the United States were reported in $2020[14,15]$ and a seventh strain, C5, isolated from carrot, is reported in this study. Chromosome sizes of these genomes were similar in size to strain R8-A2 ${ }^{\mathrm{T}}$ ( 1.6 Mbp), although most of the U.S. strains were slightly larger in size. Additionally, the number of predicted protein coding regions was higher in U.S. strains compared to the R8-A2 ${ }^{\mathrm{T}}$ genome. One set of rRNA genes and 32 tRNA genes were predicted in U.S. strains, which is consistent with the R8-A2 ${ }^{\mathrm{T}}$ strain [31].

Phylogenetic analyses between $S$. citri strains showed citrus strains C189 from southern California and R8-A2 from Morocco clustered together. C189 was originally obtained in 1957 from Washington Navel in Riverside, California by graft transmission to sweet orange seedling [4] and has been continuously maintained in the greenhouse. R8-A2 was originally obtained from Washington Navel in Morocco by graft transmission to sour orange [32]. Therefore, both strains were isolated and cultured from greenhouse citrus hosts many years after initially acquired and sequenced. Strains LB 319, BLH-13, BLH$\mathrm{MB}$, and BR12 clustered together. In these cases, S. citri was isolated and cultured directly from these field sources and sequenced. $\mathrm{CC}-2$ and $\mathrm{C} 5$, which originated from annual hosts with similar row crop ecologies, clustered together in a separate clade. Moreover, the analysis of core orthologous genes suggested that strains from citrus were very closely related and BLH strains were more closely related to citrus strains than those from Chinese cabbage or carrot. S. citri strain GII3-3X, isolated from C. haematopceps, did not group with strains isolated from BLHs from California, but this may be due to the incomplete genome sequence of GII3-3X.

A high level of homology and synteny was observed between the S. citri strains in this study, with some dissimilar regions and genomic rearrangements appearing in the center region of the chromosome. However, comparison with the most closely related species, S. phoeniceum and S. kunkelii, showed that the chromosomal organization is largely rearranged and exhibits much lower levels of sequence similarity. S. phoeniceum is associated with lethal yellows in periwinkle [33], while $S$. kunkelii causes corn stunt disease of Zea mays L. [34].
Large rearrangements were also observed when comparing S. citri to S. melliferum, a honeybee pathogen [35]. When comparing gene content, $S$. citri strains shared approximately $80 \%$ of the homologous gene clusters observed, with about $3 \%$ of gene clusters being unique to each strain. However, S. citri strain LB 319 shared approximately $64 \%$ of gene clusters with $S$. phoeniceum and S. kunkelii, while about $23 \%$ of gene clusters were unique to $S$. citri. These differences may be caused by differential gene loss, phage-mediated horizontal gene acquisition, and by ecological and biological diversification $[35,36]$.

Moreover, some of this variation may be due to variation in prophage sequences [37], which are viral or phage genomic DNA sequences integrated into a bacterial genome. S. citri is highly susceptible to viral invasion, due to its lack of a cell wall [38]. Between seventeen and twenty-five areas of the genome were predicted to contain prophage insertions in the $S$. citri genomes studied which contributed to the variations in chromosome size. Most of these sequences observed in S. citri are homologous to $\mathrm{SpV} 1$, a plectrovirus, and were dispersed throughout the genome [37]. PHASTER analysis demonstrated that SpV1 was prevalent throughout the chromosome of all seven S. citri strains, but the number and positions were inconsistent (Supplemental Fig. S3). SpV1 viral sequences have been associated with major variations of the S. citri genome [39]. These viral sequences, integrated into the Spiroplasma chromosome, can have a large effect on genome stability. A model for the evolution of the Spiroplasma genome has been linked to viral invasion, which could account for intraspecific genome size variation, low conservation in chromosomal organization, and a gain of lineage-specific genes [36]. The rearrangements and genome instability are apparent in pairwise comparisons of $S$. citri strains, and even more so when compared to their closest relatives, $S$. phoeniceum and S. kunkelii. Viral invasions likely promoted these rearrangements in plant pathogenic bacteria and could attribute to their adaptation to different hosts. In contrast to SpV1, multiple copies of phage sequences homologous to SVTS2 were present in one specific, repetitive region in all the $S$. citri strains studied (Supplementary Fig. S3). Integration of SVTS2 viral sequences into the chromosome of $S$. citri has been associated with the resistance of $S$. citri to spiroplasma virus SVTS2 [40]. This may be why SVTS2 sequences are not prevalent throughout the genome and repeating elements containing SVTS2 sequences are conserved across strains.

S. citri does not have specialized protein secretion apparatus like the Type II and Type III secretion systems, but instead utilizes the sec-dependent protein export pathways S. citri does not have T4SS. Components of 
the T4SS are present and highly conserved in S. citri strains analyzed in this study. However, their importance in virulence has yet to be verified. T4SSs are related to bacterial conjugation systems and secrete substrates into a wide range of target cells, including other bacteria and eukaryotic cells. T4SSs are known to play a role in pathogenesis in a wide range of bacteria by genetic exchange and delivery of effector molecules to target cells [41].

Fructose operon genes are major virulence components in S. citri, which utilizes fructose for pathogenicity and growth in plants [29]. The fructose operon consists of three genes: fruR, fruA, and fruK. S. citri mutants of $f r u R$, which likely encodes for the putative regulator protein of the fructose operon, abolished expression of all three genes of the operon. This mutant exhibited severely impaired pathogenicity, which could be restored when the mutant was complemented with functional fructose operon genes [30]. This work proposed an explanation of the role of fructose utilization in the pathogenicity of $S$. citri, suggesting that companion cells in the plant host compete for fructose. S. citri uses fructose as a carbon and energy source, resulting in a reduced fructose concentration in the plant companion cells, modifying the distribution of photoassimilates, leading to disease symptoms [30].

Every S. citri strain studied had a unique pattern of extrachromosomal DNA and the presence or absence, position (free or integrated), and number of these sequences is a significant source of variation among strains [42]. After several years of maintenance in plants, S. citri strain BR3-G showed chromosomal rearrangements compared to strain BR3-T, which was transmitted from plant to plant by the BLH [39]. Strain BR3-G was found to be non-transmissible by the BLH which was correlated to a large deletion of a SpV1-related transposase gene [39]. Prolonged cultivation of bacteria has been reported to cause free plasmid DNA to be integrated into the chromosome through recombination events [43-45]. Strains isolated from BLH examined in this study contained two or three plasmids with predicted prophage sequences. The strains isolated from plants exhibited one or no plasmids with predicted prophage sequences. The plasmids that contain viral sequences were homologous to those in the chromosome of S. citri strain R8-A2. It is plausible that after transmission by the BLH to plants, plasmids containing viral sequences could be incorporated by recombination with chromosomal plectroviral sequences. This would result in fewer plasmids in perennial plants compared to annual plants, which was observed in this study.

Plasmids of phytoplasmas and spiroplasmas are known to be involved in insect transmissibility [46-49]. All the newly sequenced $S$. citri strains contained at least one plasmid with high homology to plasmid pSci6, identified in S. citri strain GII3-3X [24]. pSci6 plasmid encodes P32 protein, associated with insect transmissibility, and this plasmid confers insect transmissibility into nontransmissible strains of S. citri [50]. P32 has been suggested to interact with surface membrane proteins and may be necessary, but not sufficient for spiroplasma adhesion and invasion of insect cells [51]. In strain GII-3, eight proteins belonging to the ScARP protein family, which are expected to be involved in S. citri adhesion to insect cells, were encoded by five plasmids [24-26]. In previous studies, a loss of the high-molecular-mass plasmids carrying ScARP genes was correlated with a nontransmissible phenotype [51]. ScARP genes were found to be present in plasmids isolated from perennial crops and the leafhopper vector in this study. These plasmids are highly similar to $\mathrm{pSci} 2$ and $\mathrm{pSci} 5$ from $S$. citri strain GII3-3X and pBJS-O from S. citri strain BR3-3X [24, 52] (Supplementary Table S1). Interestingly, no fulllength ScARPs were predicted in C189 or LB 319 plasmids. The lack of additional plasmids containing ScARP genes, seen in strains obtained from perennial crops, suggest these strains could have lost their ability to be transmitted by the BLH.

Several other genes have been assigned putative functions in plasmid pSci6. This included soj-parA, which is involved in DNA partitioning, and traG and $m o b$, which are associated with DNA transfer and are suggested to be involved in a Type IV secretory pathway [24]. A coding region was also identified in plasmid pScp-C189-1, which has homology to a plasmid replication-relaxation (relaxase) family protein. Plasmids in S. citri have been suggested to be horizontally transferred between cells by conjugation [24]. Several important genes are at the core of plasmid conjugation, including Type IV coupling proteins and relaxases [53]. The traG and $m o b$ genes found in pSci6 correspond to VirB4/D4 components of the type IV secretion pathway, which allows for the translocation of DNA through cytoplasmic membranes [54]. Walled bacteria require many components in their conjugation system; however, these components may not be necessary in S. citri, a wall-less bacterium. In addition to traG and $m o b$, Saillard et al. suggested that pSci6 should contain a relaxase, but this family of proteins was not reported [24]. The replicationrelaxation (relaxase) family protein is essential for plasmid replication and plasmid DNA relaxation, part of conjugative DNA transfer in bacteria [55-57]. A BLAST search of the coding sequences in pScpC189-1 revealed homology to a replication-relaxation family protein. This further supports previous studies that reported genetic exchanges by a conjugation-like process in S. citri [58]. The genes identified in this plasmid encode for virulence-associated proteins 
involved in adhesion and conjugal DNA transfer. The occurrence of this persistent, conserved plasmid suggests it plays an important role in this pathogen.

\section{Conclusion}

Six Spiroplasma citri genomes were published recently, but were not fully analyzed $[14,15]$. Those sequences, along with $\mathrm{C} 5$, a strain de novo assembled in this study, greatly expanded the availability of $S$. citri genomes and allowed performance of extensive in silico comparative genomic studies that provide insights into this organism's genetic diversity and evolution. An extremely high level of homogeneity was observed in the chromosomal contigs across S. citri strains. Variation in plasmid number may play an important role in insect transmission and virulence. Moreover, differences in genome size and stability appear to result from variations in number and site of plectroviral sequences inserted into the genome. These features likely contribute to $S$. citri adaptation to different hosts and transmissibility by leafhopper vectors. Further studies will be necessary to validate the roles of plasmids and viral insertion sequences in S. citri strains isolated from various hosts.

\section{Methods}

\section{Strain isolation and DNA preparation}

Cultures of $S$. citri strains CC-2, C189, BR-12, LB 319, BLH-13, and BLH-MB were isolated, and DNA extracted in a previous study $[14,15]$. S. citri strain C5 was collected in 2005 from carrot growing in NW Bakersfield, California. Briefly, S. citri was isolated and grown in LD8 medium [59]. Later the cultures were triple cloned and stored at $80^{\circ} \mathrm{C}$ until further use. Cultures were re-established and total genomic DNA was extracted by CTAB [60] or by DNeasy Blood and Tissue Extraction kit (Qiagen). Collection details of S. citri in this study are listed in Table 1.

\section{Whole-genome shotgun sequencing}

S. citri strain C5 was sequenced on the Oxford Nanopore (Oxford, United Kingdom) MinION platform [61]. The library was prepared with Oxford Nanopore (Oxford, United Kingdom) Rapid Barcoding Kit-SQKRBK004 according to the manufacturer's specifications. Data was collected using MinION Release 19.10.1. Bases were called using Guppy v.3.4.5 and the adapter screening and quality filtering of raw sequencing data were performed using Fastp v 0.20 .0 [62]. Remaining S. citri strains' genomes were sequenced previously on PacBio (Menlo Park, CA, USA) RS II platform [14, 15].

\section{De novo sequencing assembly}

Sequences from S. citri strains CC-2, C189, BR-12, LB 319, BLH-13, and BLH-MB were reported previously $[14,15]$. Briefly, raw reads were filtered, subreads were established by PacBio, and assembled into contigs using Canu 1.8 [63]. For S. citri strain C5, contigs were assembled using Canu 1.8. An additional polishing step was performed by medaka v 1.0.3 (Oxford Nanopore Technologies) and frame-shiftcorrected by DIAMOND v 0.9.28 [64] and MEGAN v 6.18.4 [65], following the pipeline described by Arumugam et al. [66]. Approximately 500 bp segments from each end of a contig were used for BLASTn search to check the contig singularity. Appropriate reads connecting both ends were used for enclosure. The chromosome and plasmid status of each contig were further confirmed by BLASTn analyses against the GenBank database. The genome sequence data was deposited in the NCBI database (accession numbers shown in Table 2). Annotation of each contig was performed by the NCBI Prokaryotic Genome Annotation Pipeline (PGAP) [67].

\section{Phylogenetic analyses}

The 16S rRNA sequences of thirty-nine Spiroplasma species were obtained from the NCBI database. Sequence alignments were carried out with the PRANK alignment tool [68]. Maximum-likelihood approach was used to reconstruct the phylogenetic tree using RAxML software [69]. Bootstrapping was performed with 1000 replicates. The resulting phylogeny was visualized with FigTree [16].

Orthologous genes of S. citri isolates were predicted using the OrthoMCL v. 2.0 pipeline [70]. All-versus-all BLASTN ( $E$ value $<10^{-5}$, alignment coverage $>50 \%$ ) comparison of all gene sequences for each species was performed and orthologous genes were clustered by OrthoMCL v. 2.0. Multiple sequence alignment was done with PRANK v. 170,427 [71]. The sequence alignments were concatenated by FASconCAT v. 1.1, yielding a gene super-matrix [72]. Maximum-likelihood approach was used to reconstruct the phylogenetic tree using RAxML v. 8.2 software with 1000 bootstrap replicates [69]. The resulting phylogeny was visualized using FigTree v. 1.4.3 [16].

\section{Bioinformatics analysis}

Large genome comparison of eight $S$. citri sequences was computed and visualized with the use of BLAST Ring Image Generator (BRIG) v 0.95 [17]. Pairwise genome alignment was achieved by the Lastz v. 1.04 program [19]. The results were visualized using AliTV v. 1.0 [18]. Shared and genome-specific genes were identified between the $S$. citri strains isolated from different sources and among S. citri LB 319, S. kunkelii CR2-3X, and S. phoeniceum P40. The sequence similarity search step in the OrthoMCL analysis was conducted at the nucleotide level [70]. Functional annotation of COG was done using eggNOG-mapper [73]. Prophage sequences were predicted using PHASTER online server [74]. 


\section{Abbreviations}

PGAP: Prokaryotic Genome Annotation Pipeline; CSD: citrus stubborn disease; CC: Chinese cabbage; LB: Liberty Bell; BR: brittle root; BLH: beet leafhopper; BRIG: BLAST Ring Image Generator; COG: cluster of orthologs groups; SCARPS: S. citri adhesion-related proteins; PHASTER: PHAge Search Tool Enhanced Release

\section{Supplementary Information}

The online version contains supplementary material available at https://doi. org/10.1186/s12864-021-07637-8.

Additional file 1: Supplementary Table S1. BLASTn similarity search of Spiroplasma citri putative plasmid (contigs) against available Spiroplasma sequences deposited in NCBI database.

Additional file 2: Supplementary Table S2. GenBank accession numbers for the $16 \mathrm{~S}$ rRNA Spiroplasma sequences used for phylogenetic analyses in Fig. 1.

Additional file 3: Supplementary Table S3. COG functional categories of Spiroplasma citri LB319

Additional file 4: Supplementary Table S4. Summary of PHAge Search Tool Enhanced Release (PHASTER) analysis of Spiroplasma citri strains

Additional file 5: Supplementary Fig. S1. Phylogenetic analysis of Spiroplasma strains. Maximum-likelihood phylogeny of Spiroplasma based on core orthologous genes. In total, 601 orthologous genes were concatenated, and a maximum-likelihood approach was used to generate the phylogeny with 1000 bootstrap replicates. Bootstrap values are indicated at each node. The resulting phylogeny was visualized using FigTree v.1.4.3 [70]. S. citri strains analyzed in this report are underlined.

Additional file 6: Supplementary Fig. S2. Dot-Matrix representation of a BLASTn comparison of complete Spiroplasma citri genome sequences. The chromosome of each newly assembled strain (X-axis) was compared to the reference sequence, strain R8-A2 (Y-axis). A) C189; B) LB 319; C) BR12; D) C(-2; E) C5; F) BLH-13; G) BLH-MB.

Additional file 7: Supplementary Fig. S3. Predicted prophage sequences in Spiroplasma citri genomes. Prophage annotation was performed by PHASTER (PHAge Search Tool - Enhanced Release). The program predicts the completeness of the predicted prophages, based on the proportion of phage genes in the identified region. Green bars are scored as intact (score $>90$ ); blue bars are questionable (score 70-90); red bars are incomplete (score $<70$ ). Strains with plasmids predicted to contain phage genes are included (Fig. S3B, E, F, and G). Approximate location of repetitive region identified by dot-matrix pairwise sequence comparisons (Supplementary Fig. S2) is highlighted in yellow.

\section{Acknowledgements}

We thank Robert DeBorde of the United States Department of AgricultureAgricultural Research Service, San Joaquin Valley Agricultural Sciences Center, Parlier, CA for technical assistance. Jacqueline Fletcher and Kitty Cardwell, Entomology \& Plant Pathology Department, Institute of Biosecurity and Microbial Forensics, Oklahoma State University, Stillwater, Oklahoma, are gratefully acknowledged for providing cultures of S. citri strain BR12 and C5. We acknowledge the dedication of the past and current Citrus Clonal Protection Program (CCPP) personnel at the University of California, Riverside for maintaining in planta the originally cultured S. citri isolate C189 since 1957 [4]. Mention of trade names or commercial products in this publication is solely for providing specific information and does not imply recommendation or endorsement by the USDA. USDA is an equal opportunity provider and employer.

\section{Authors' contributions}

RKY, GV, FO and DP conceptualized the study and acquired the S. citri cultures. Funds for this research were from grants to RKY and GV. DP, YM and VS cultured the pathogens and purified the DNA. FO supervised the PacBio submissions. AE and TD cultured, purified DNA, and provided raw sequence data for S. citri strain C5, JC provided technical assistance for genome assembly and bioinformatics, $\mathrm{SH}$ provided some technical assistance. RR and ST conducted data curation and analysis. RR, ST and RY wrote the manuscript and DP, SH, JC, GC, and GV edited the manuscript. All author(s) read and approved the final manuscript.

\section{Funding}

This work was supported by USDA 2034-22000-013-10R and two grants from the Citrus Research Board: Project 5300-191 to R. Yokomi; and Project 5100-153 to G. Vidalakis. G. Coaker and S. Thapa were supported by grants from the USDA (2019-70016-29796, 2016-70016-24833). Additional support for this work was provided in part by the Citrus Research Board (Project 6100 and 5300-179), the USDA National Institute of Food and Agriculture, Hatch Project 1020106 and the National Clean Plant Network (AP17PPOS\&T00C118 and AP18PPQS\&TO0C107). The sequencing was carried out at the DNA Technologies and Expression Analysis Cores at the UC Davis Genome Center, supported by NIH Shared Instrumentation Grant 1S100D010786-01. The funding bodies played no role in the design of the study and collection, analysis or interpretation of data and writing of the manuscript.

\section{Availability of data and materials}

The data described in this study can be freely and openly accessed from the $\mathrm{NCBI}$ database. All sequence data has been deposited in GenBank under the accession numbers CP042472-CP042475, CP0426368-CP046373, CP047426CP047446, and CP053304-CP053311. The versions described in this paper are the first versions. PacBio sequencing reads for BioProject PRJNA558054 have been deposited in the NCBI Sequence Read Archive (SRA) under accession number SRR9903453 for CC-2. PacBio sequencing reads for BioProject PRJNA591027 have been deposited in the NCBI SRA under accession numbers SRR10843927 for C189; SRR10507068 for LB 319; SRR10507067 for BR12; SRR10507065 for BLH-13; and SRR10507066 for BLH-MB. Nanopore sequencing reads for BioProject PRJNA625113 have been deposited in the NCBI SRA under accession number SRR11536473 for C5. S. citri cultures for BLH-13, BLH-MB, BR12, LB 319, and CC-2 have been deposited in ATCC no. SD-7532-7535 and SD-7278, respectively. However, ATCC Biorepository Service Agreement 2019BRS-00049 maintains confidentiality of information regarding these cultures. C189 and C5 cultures are available from the corresponding author.

\section{Declarations}

Ethics approval and consent to participate

Not applicable.

\section{Consent for publication}

Not applicable.

\section{Competing interests}

The authors declare that they have no competing interests.

\section{Author details}

${ }^{1}$ Crop Diseases, Pests, and Genetics Research Unit, San Joaquin Valley Agricultural Sciences Center, USDA Agricultural Research Service, Parlier, CA 93648, USA. ${ }^{2}$ Department of Plant Pathology, University of California, Davis, CA 95616, USA. ${ }^{3}$ Department of Microbiology and Plant Pathology, University of California, Riverside, CA 92521, USA. ${ }^{4}$ Department of Entomology \& Plant Pathology and Institute of Biosecurity and Microbial Forensics, Oklahoma State University, Stillwater, OK 74078, USA. ${ }^{5}$ Citrus Pest Detection Program, Central California Tristeza Eradication Agency, Tulare, CA 93274, USA.

Received: 2 September 2020 Accepted: 21 April 2021

Published online: 22 May 2021

References

1. Whitcomb RF. The mycoplasmas v3: plant and insects mycoplasmas. Amsterdam: Elsevier; 2012

2. Gasparich GE. Spiroplasmas: evolution, adaptation and diversity. Front Biosci. 2002:7:d619-40.

3. Regassa LB, Gasparich GE. Spiroplasmas: evolutionary relationships and biodiversity. Front Biosci. 2006;11(1):2983-3002. https://doi.org/10.2741/2027.

4. Fudl-Allah AESA, Calavan EC, Igwegbe ECK. Culture of a mycoplasmalike organism associated with stubborn disease of citrus. Phytopathology. 1972: 62(7):729-31. https://doi.org/10.1094/Phyto-62-729. 
5. Fletcher J. Brittle root disease of horseradish: evidence for an etiological role of Spiroplasma citri. Phytopathology. 1981;71(10):1073-80. https://doi.org/1 0.1094/Phyto-71-1073.

6. Lee I-M, Bottner KD, Munyaneza JE, Davis RE, Crosslin JM, du Toit LJ, et al. Carrot purple leaf: a new spiroplasmal disease associated with carrots in Washington state. Plant Dis. 2006;90(8):989-93. https://doi.org/10.1094/PD90-0989.

7. Chen TA, Liao CH. Corn stunt spiroplasma: isolation, cultivation, and proof of pathogenicity. Science. 1975;188(4192):1015-7. https://doi.org/10.1126/ science.188.4192.1015.

8. Saillard C, Vignault JC, Bove JM, Raie A, Tully JG, Williamson DL, et al. Spiroplasma phoeniceum sp. nov., a new plant-pathogenic species from Syria. Int J Syst Bacteriol. 1987;37(2):106-15. https://doi.org/10.1099/002 07713-37-2-106

9. Liu HY, Gumpf DJ, Oldfield GN, Calavan EC. The relationship of Spiroplasma citri and Circulifer tenellus. Phytopathology. 1983;73(4):585-90. https://doi. org/10.1094/Phyto-73-585.

10. Fos A, Bové JM, Lallemand J, Saillard C, Vignault JC, Ali Y, et al. The leafhopper Neoaliturus haematoceps (Mulsant \& Rey) is a vector of Spiroplasma citri in the Mediterranean. Ann Inst Pasteur Microbiol. 1986; 137A(1):97-107. https://doi.org/10.1016/s0769-2609(86)80009-6.

11. Brown DR, Whitcomb RF, Bradbury JM. Revised minimal standards for description of new species of the class Mollicutes (division Tenericutes). Int J Syst Evol Microbiol. 2007;57(11):2703-19. https://doi.org/10.1099/ijs.0.64722-0.

12. Didelot $X$, Bowden R, Wilson DJ, Peto TEA, Crook DW. Transforming clinical microbiology with bacterial genome sequencing. Nat Rev Genet. 2012;13(9): 601-12. https://doi.org/10.1038/nrg3226.

13. Amarasinghe SL, Su S, Dong X, Zappia L, Ritchie ME, Gouil Q. Opportunities and challenges in long-read sequencing data analysis. Genome Biol. 2020; 21:1-16.

14. Yokomi R, Rattner R, Osman F, Maheshwari Y, Selvaraj V, Pagliaccia D, et al. Whole genome sequence of five strains of Spiroplasma citri isolated from different host plants and its leafhopper vector. BMC Res Notes. 2020;13:1-4.

15. Yokomi R, Chen J, Rattner R, Selvaraj V, Maheshwari Y, Osman F, et al. Genome sequence resource for Spiroplasma citri, strain CC-2, associated with citrus stubborn disease in California. Phytopathology. 2020;110(2):2546. https://doi.org/10.1094/PHYTO-08-19-0304-A.

16. Rambaut A. FigTree v1. 4. 2012. http://tree.bio.ed.ac.uk/software/figtree/.

17. Alikhan N-F, Petty NK, Ben Zakour NL, Beatson SA. BLAST ring image generator (BRIG): simple prokaryote genome comparisons. BMC Genomics. 2011;12(1):402. https://doi.org/10.1186/1471-2164-12-402.

18. Ankenbrand MJ, Hohlfeld S, Hackl T, Förster F. AliTV-interactive visualization of whole genome comparisons. PeerJ Comput Sci. 2017;3:e116. https://doi.org/10.7717/peerj-cs.116.

19. Harris RS. Improved pairwise alignment of genomic DNA. Ph.D. Dissertation: Pennsylvania State University; 2007.

20. Elwell LP, Shipley PL. Plasmid-mediated factors associated with virulence of bacteria to animals. Annu Rev Microbiol. 1980;34(1):465-96. https://doi.org/1 0.1146/annurev.mi.34.100180.002341.

21. Diard M, Hardt W-D. Evolution of bacterial virulence. FEMS Microbiol Rev. 2017;41(5):679-97. https://doi.org/10.1093/femsre/fux023.

22. Klümper U, Riber L, Dechesne A, Sannazzarro A, Hansen LH, Sørensen SJ, et al. Broad host range plasmids can invade an unexpectedly diverse fraction of a soil bacterial community. ISME J. 2015;9(4):934-45. https://doi. org/10.1038/ismej.2014.191

23. Jain A, Srivastava P. Broad host range plasmids. FEMS Microbiol Lett. 2013; 348(2):87-96. https://doi.org/10.1111/1574-6968.12241.

24. Saillard C, Carle P, Duret-Nurbel S, Henri R, Killiny N, Carrère S, et al. The abundant extrachromosomal DNA content of the Spiroplasma citri GII3-3X genome. BMC Genomics. 2008:9:1-13.

25. Yu J, Wayadande AC, Fletcher J. Spiroplasma citri surface protein P89 implicated in adhesion to cells of the vector Circulifer tenellus. Phytopathology. 2000:90(7):716-22. https://doi.org/10.1094/PHYTO.2000.90.7.716.

26. Berg M, Melcher U, Fletcher J. Characterization of Spiroplasma citri adhesion related protein SARP1, which contains a domain of a novel family designated sarpin. Gene. 2001;275(1):57-64. https://doi.org/10.1016/S03 78-1119(01)00655-2.

27. Renaudin J, Bové JM. SpV1 and SpV4, spiroplasma viruses with circular single-stranded DNA genomes, and their contribution to the molecular biology of spiroplasmas. Adv Virus Res. 1994;44:429-63. https://doi.org/10.1 016/S0065-3527(08)60335-8.
28. Sha Y, Melcher U, Davis RE, Fletcher J. Common elements of spiroplasma plectroviruses revealed by nucleotide sequence of SVTS2. Virus Genes. 2000; 20(1):47-56. https://doi.org/10.1023/A:1008108106916.

29. Dubrana MP, Béven L, Arricau-Bouvery N, Duret S, Claverol S, Renaudin J, et al. Differential expression of Spiroplasma citri surface protein genes in the plant and insect hosts. BMC Microbiol. 2016;16(1):53. https://doi.org/10.11 86/s12866-016-0666-y.

30. Gaurivaud P, Danet JL, Laigret F, Garnier M, Bové JM. Fructose utilization and phytopathogenicity of Spiroplasma citri. Mol Plant Microbe In. 2000; 13(10):1145-55. https://doi.org/10.1094/MPMI.2000.13.10.1145.

31. Davis RE, Shao J, Zhao Y, Gasparich GE, Gaynor BJ, Donofrio N. Complete genome sequence of Spiroplasma citri strain R8-A2T, causal agent of stubborn disease in Citrus species. Genome Announc. 2017;5:e00206-17.

32. Saglio P, L'Hospital M, Lafleche D, et al. Spiroplasma citri gen. And sp. n.: a mycoplasma-like organism associated with "stubborn" disease of citrus. Int J Syst Evol Microbiol. 1972;23(3):191-204.

33. Nejat N, Vadamalai G, Sijam K, Dickinson M. First report of Spiroplasma citri (-induced) associated with periwinkle lethal yellows in Southeast Asia. Plant Dis. 2011;95(10):1312. https://doi.org/10.1094/PDIS-03-11-0251.

34. Whitcomb RF, Chen TA, Williamson DL, Liao C, Tully JG, Bove JM, et al. Spiroplasma kunkelii sp. nov.: characterization of the etiological agent of corn stunt disease. Int J Syst Bacteriol. 1986;36(2):170-8. https://doi.org/10.1 099/00207713-36-2-170

35. Lo W-S, Chen L-L, Chung W-C, Gasparich GE, Kuo C-H. Comparative genome analysis of Spiroplasma melliferum IPMB4A, a honeybee-associated bacterium. BMC Genomics. 2013;14(1):22. https://doi.org/10.1186/1471-21 64-14-22.

36. Ku C, Lo W-S, Chen L-L, Kuo C-H. Complete genomes of two dipteranassociated spiroplasmas provided insights into the origin, dynamics, and impacts of viral invasion in spiroplasma. Genome Biol Evol. 2013;5(6):115164. https://doi.org/10.1093/gbe/evt084.

37. Melcher U, Sha Y, Ye F, Fletcher J. Mechanisms of Spiroplasma genome variation associated with SpVI-like viral DNA inferred from sequence comparisons. Microb Comp Genomics. 1999;4(1):29-46. https://doi.org/10.1 089/omi.1.1999.4.29.

38. Rakonjac J, Bennett NJ, Spagnuolo J, Gagic D, Russel M. Filamentous bacteriophage: biology, phage display and nanotechnology applications. Curr Issues Mol Biol. 2011;13(2):51-76.

39. Ye F, Melcher U, Rascoe JE, Fletcher J. Extensive chromosome aberrations in Spiroplasma citri strain BR3. Biochem Genet. 1996;34(7-8):269-86. https://doi. org/10.1007/BF02399947.

40. Sha $Y$, Melcher U, Davis RE, Fletcher J. Resistance of Spiroplasma citri lines to the virus SVTS2 is associated with integration of viral DNA sequel into host chromosomal and extrachromosomal DNA. Appl Environ Microbiol. 1995; 61(11):3950-9. https://doi.org/10.1128/AEM.61.11.3950-3959.1995.

41. Cascales E, Christie PJ. The versatile bacterial type IV secretion systems. Nat Rev Microbiol. 2003;1(2):137-49. https://doi.org/10.1038/nrmicro753.

42. Melcher U, Fletcher J. Genetic variation in Spiroplasma citri. Eur J Plant Pathol. 1999;105(6):519-33. https://doi.org/10.1023/A:1008757716803.

43. Nur I, LeBlanc DJ, Tully JG. Short, interspersed, and repetitive DNA sequences in Spiroplasma species. Plasmid. 1987;17(2):110-6. https://doi. org/10.1016/0147-619X(87)90017-5.

44. Biškup UG, Strle F, Ružić-Sabljić E. Loss of plasmids of Borrelia burgdorferi sensu lato during prolonged in vitro cultivation. Plasmid. 2011;66(1):1-6. https://doi.org/10.1016/j.plasmid.2011.02.006.

45. Campbell AM. Chromosomal insertion sites for phages and plasmids. J Bacteriol. 1992;174(23):7495-9. https://doi.org/10.1128/JB.174.23.7495-7499.1992.

46. Nishigawa H, Oshima K, Kakizawa S, Jung H-Y, Kuboyama T, Miyata S, et al. A plasmid from a non-insect-transmissible line of a phytoplasma lacks two open reading frames that exist in the plasmid from the wild-type line. Gene. 2002;298(2):195-201. https://doi.org/10.1016/S0378-1119(02)00975-7.

47. Oshima K, Shiomi T, Kuboyama T, Sawayanagi T, Nishigawa H, Kakizawa S, et al. Isolation and characterization of derivative lines of the onion yellows phytoplasma that do not cause stunting or phloem hyperplasia. Phytopathology. 2001;91(11):1024-9. https://doi.org/10.1094/PHYTO.2001. 91.11.1024.

48. Bai X, Fazzolari T, Hogenhout SA. Identification and characterization of traE genes of Spiroplasma kunkelii. Gene. 2004;336(1):81-91. https://doi.org/10.1 016/j.gene.2004.03.022

49. Davis RE, Dally EL, Jomantiene R, Zhao Y, Roe B, Lin S, et al. Cryptic plasmid pSKU146 from the wall-less plant pathogen Spiroplasma kunkelii encodes an 
adhesin and components of a type IV translocation-related conjugation system. Plasmid. 2005;53(2):179-90. https://doi.org/10.1016/.jplasmid.2004.09.002.

50. Berho N, Duret S, Renaudin J. Absence of plasmids encoding adhesionrelated proteins in non-insect-transmissible strains of Spiroplasma citri. Microbiology. 2006;152(3):873-86. https://doi.org/10.1099/mic.0.28541-0.

51. Killiny N, Batailler B, Foissac X, Saillard C. Identification of a Spiroplasma citr hydrophilic protein associated with insect transmissibility. Microbiology. 2006;152(4):1221-30. https://doi.org/10.1099/mic.0.28602-0.

52. Joshi BD, Berg M, Rogers J, Fletcher J, Melcher U. Sequence comparisons of plasmids pBJS-O of Spiroplasma citri and pSKU146 of S. kunkelii: implications for plasmid evolution. BMC Genomics. 2005;6(1):175. https://doi.org/10.11 86/1471-2164-6-175.

53. Smillie C, Garcillán-Barcia MP, Francia MV, Rocha EPC, de la Cruz F. Mobility of plasmids. Microbiol Mol Biol Rev. 2010;74(3):434-52. https://doi.org/10.112 8/MMBR.00020-10.

54. Chen I, Christie PJ, Dubnau D. The ins and outs of DNA transfer in bacteria. Science. 2005;310(5753):1456-60. https://doi.org/10.1126/science.1114021.

55. Zechner EL, de la Cruz F, Eisenbrandt R, Grahn AM, Koraimann G, Lanka E, et al. Conjugative-DNA transfer processes. In: Thomas CM, editor. Horizontal gene pool. Amsterdam: Harwood Academic Publishers; 2000. p. 93-180.

56. Francia MV, Varsaki A, Garcillán-Barcia MP, Latorre A, Drainas C, de la Cruz F. A classification scheme for mobilization regions of bacterial plasmids. FEMS Microbiol Rev. 2004;28(1):79-100. https://doi.org/10.1016/.jemsre.2003.09.001.

57. Garcillán-Barcia MP, Francia MV, de la Cruz F. The diversity of conjugative relaxases and its application in plasmid classification. FEMS Microbiol Rev. 2009;33(3):657-87. https://doi.org/10.1111/j.1574-6976.2009.00168.x.

58. Barroso G, Labarere J. Chromosomal gene transfer in Spiroplasma citri. Science. 1988;241(4868):959-61. https://doi.org/10.1126/science.3261453.

59. Lee I-M. New media for rapid growth of Spiroplasma citri and corn stunt spiroplasma. Phytopathology. 1984;74(1):84-9. https://doi.org/10.1094/Phyto74-84.

60. Doyle J. DNA protocols for plants. In: Hewitt GM, Johnston AWB, Young JPW, editors. Molecular techniques in taxonomy. Berlin, Heidelberg: Springer; 1991. p. 283-93. https://doi.org/10.1007/978-3-642-83962-7_18,

61. Mikheyev AS, Tin MMY. A first look at the Oxford Nanopore MinION sequencer. Mol Ecol Resour. 2014;14(6):1097-102. https://doi.org/10.1111/1 755-0998.12324

62. Chen S, Zhou Y, Chen Y, Gu J. fastp: an ultra-fast all-in-one FASTQ preprocessor. Bioinformatics. 2018;34(17):i884-90. https://doi.org/10.1093/ bioinformatics/bty560

63. Koren S, Walenz BP, Berlin K, Miller JR, Bergman NH, Phillippy AM. Canu: scalable and accurate long-read assembly via adaptive $\mathrm{k}$-mer weighting and repeat separation. Genome Res. 2017;27(5):722-36. https://doi.org/10.1101/ gr.215087.116.

64. Buchfink B, Xie C, Huson DH. Fast and sensitive protein alignment using DIAMOND. Nat Methods. 2015;12(1):59-60. https://doi.org/10.1038/nmeth.3176

65. Huson DH, Auch AF, Qi J, Schuster SC. MEGAN analysis of metagenomic data. Genome Res. 2007;17(3):377-86. https://doi.org/10.1101/gr.5969107.

66. Arumugam K, Bağcı C, Bessarab I, Beier S, Buchfink B, Górska A, et al. Annotated bacterial chromosomes from frame-shift-corrected long-read metagenomic data. Microbiome. 2019;7:1-13.

67. Tatusova T, DiCuccio M, Badretdin A, Chetvernin V, Nawrocki EP, Zaslavsky L, et al. NCBI prokaryotic genome annotation pipeline. Nucleic Acids Res. 2016; 44(14):6614-24. https://doi.org/10.1093/nar/gkw569.

68. Löytynoja A, Goldman N. An algorithm for progressive multiple alignment of sequences with insertions. PNAS. 2005;102(30):10557-62. https://doi.org/1 0.1073/pnas.0409137102.

69. Stamatakis A. RAxML-VI-HPC: maximum likelihood-based phylogenetic analyses with thousands of taxa and mixed models. Bioinformatics. 2006: 22(21):2688-90. https://doi.org/10.1093/bioinformatics/btl446.

70. Li L, Stoeckert CJ, Roos DS. OrthoMCL: identification of ortholog groups for eukaryotic genomes. Genome Res. 2003;13(9):2178-89. https://doi.org/10.11 01/gr.1224503.

71. Löytynoja A. Phylogeny-aware alignment with PRANK. Methods Mol Biol. 2014;1079:155-70. https://doi.org/10.1007/978-1-62703-646-7_10.

72. Kück P, Meusemann K. FASconCAT: convenient handling of data matrices. Mol Phylogenet Evol. 2010;56(3):1115-8. https://doi.org/10.1016/j.ympev.201 0.04.024.

73. Huerta-Cepas J, Forslund K, Coelho LP, Szklarczyk D, Jensen LJ, von Mering $C$, et al. Fast genome-wide functional annotation through orthology assignment by eggNOG-mapper. Mol Biol Evol. 2017;34(8):2115-22. https:// doi.org/10.1093/molbev/msx148.

74. Arndt D, Grant JR, Marcu A, Sajed T, Pon A, Liang Y, et al. PHASTER: a better, faster version of the PHAST phage search tool. Nucleic Acids Res. 2016; 44(W1):W16-21. https://doi.org/10.1093/nar/gkw387.

\section{Publisher's Note}

Springer Nature remains neutral with regard to jurisdictional claims in published maps and institutional affiliations.
Ready to submit your research? Choose BMC and benefit from:

- fast, convenient online submission

- thorough peer review by experienced researchers in your field

- rapid publication on acceptance

- support for research data, including large and complex data types

- gold Open Access which fosters wider collaboration and increased citations

- maximum visibility for your research: over $100 \mathrm{M}$ website views per year

At BMC, research is always in progress.

Learn more biomedcentral.com/submissions 